\begin{tabular}{lrr}
\hline Volume 21 & Nomor 1, Januari 2020 & Halaman 59-69 \\
URL: https://jurnal.unej.ac.id/index.php/SEMIOTIKA/index & E-ISSN: 2599-3429 & P-ISSN: 1411-5948 \\
\hline
\end{tabular}

\title{
PEMILIHAN BAHASA: INTERAKSI JUAL BELI DI PASAR TRADISIONAL KABUPATEN LUMAJANG
}

\section{LANGUAGE PREFERENCE: BUYING AND SELLING INTERACTIONS IN THE TRADITIONAL MARKET AT LUMAJANG DISTRICT}

\author{
Ana Askia Putri ${ }^{1}$, A. Erna Rochiyati ${ }^{2}$, Agustina Dewi Setyari ${ }^{3}$ \\ ${ }^{1}$ Alumni Fakultas Ilmu Budaya Universitas Jember \\ ${ }^{2,3}$ Fakultas Ilmu Budaya Universitas Jember \\ *Corresponding Author: erna.rochiyati@gmail.com \\ Informasi Artikel: \\ Dikirim: 30/7/2019; Direvisi: 26/10/2019; Diterima: 14/12/2019
}

\begin{abstract}
The sociolinguistic study is one of the interdisciplinary branches of sociology and linguistics with the object of language study as a means to communicate in the community. One of which is language selection. This study discusses the choice of language used by sellers and buyers and the factors behind the choice of language used by sellers and buyers in Randuagung District Market, Lumajang Regency. In general, this research is descriptive qualitative research. The data collection stage in this study used the listening method and proficient method. The data analysis stage used intralingual and extra lingual equivalents, presenting the results of data analysis using informal methods. The results showed that the interaction between the seller and the buyer was very communicative. The language selection in Randuagung District's market, Lumajang Regency occurred in three forms: code-switching, code-mixing, and a single language. The factors behind the choice of language are 1) participant, 2) conversation topic, and 3) function (purpose and objective) of speech. There are four types of the participant a) familiarity, b) age differences, c) ethnic background and language of speakers, and d) the presence of third parties.
\end{abstract}

Keywords: buyer-seller, language, language selection, sociolinguistic

Abstrak

Studi sosiolinguistik merupakan salah satu cabang ilmu interdisipliner antara ilmu sosiologi dan ilmu linguistik dengan objek kajian bahasa sebagai sarana komunikasi masyarakat, salah satunya adalah pemilihan bahasa. Penelitian ini membahas tentang pemilihan bahasa yang digunakan oleh penjual dan pembeli serta faktor-faktor yang melatarbelakangi terjadinya pemilihan bahasa yang digunakan oleh penjual dan pembeli di Pasar Kecamatan Randuagung, Kabupaten Lumajang. Secara umum penelitian ini termasuk dalam penelitian kualitatif deskriptif. Tahap pengumpulan data dalam penelitian ini menggunakan metode simak dan metode cakap; tahap analisis data menggunakan metode padan intralingual dan padan ekstralingual; dan tahap pemaparan hasil analisis data menggunakan metode informal. Hasil penelitian menunjukkan bahwa interaksi antara penjual dan pembeli sangat komunikatif dan pemilihan bahasa yang terjadi di pasar Kecamatan Randuagung Kabupaten Lumajang terjadi dalam tiga wujud, yaitu dalam wujud alih kode, campur kode, dan tunggal bahasa. Faktor-faktor yang melatarbelakangi pemilihan bahasa yaitu: 1) partisipan (participant), 2) topik percakapan, dan 3) fungsi 
(maksud dan tujuan) tuturan. Partisipan dibagi menjadi empat yaitu: a) keakraban, b) perbedaan umur, c) latar belakang etnik dan bahasa penutur, serta d) hadirnya pihak ketiga.

Kata kunci: penjual-pembeli, bahasa, pemilihan bahasa, sosiolingusitik

\section{PENDAHULUAN}

Pemilihan bahasa sangat erat kaitannya dengan permasalahan penggunaan bahasa pada masyarakat dwibahasa ataupun multibahasa. Hal ini karena penggunaan bahasa yang ada dalam masyarakat sekurang-kurangnya ada dua, yaitu bahasa daerah atau yang biasanya juga menjadi bahasa ibu dan bahasa Indonesia sebagai bahasa nasional. Penguasaan dua bahasa atau lebih inilah yang menimbulkan pemilihan bahasa oleh masyarakat yang menguasai lebih dari satu bahasa ini. Menurut Fasold (dalam Chaer dan Agustina, 2010:153) pemilihan bahasa tidak sesederhana yang kita bayangkan, yakni memilih sebuah bahasa secara keseluruhan (whole language) dalam suatu peristiwa komunikasi. Kita membayangkan seseorang menguasai dua bahasa atau lebih harus memilih bahasa yang akan digunakan. Misalnya, seseorang yang menguasai bahasa Jawa dan bahasa Indonesia harus memilih salah satu di antara kedua bahasa itu ketika berbicara kepada orang lain dalam peristiwa komunikasi.

Orang yang dapat menggunakan kedua bahasa itu disebut bilingual (dwibahasawan), sedangkan kemampuan untuk menggunakan dua bahasa disebut bilingualitas (kedwibahasawanan). Selain ada istilah bilingualisme ada juga istilah multilingualisme (dalam bahasa Indonesia disebut juga keanekabahasaan) yakni keadaan digunakannya lebih dari dua bahasa oleh seseorang dalam pergaulannya dengan orang lain secara bergantian (Chaer dan Agustina, 2010:85).

Kecamatan Randuagung merupakan sebuah kecamatan di Kabupaten Lumajang yang terletak di wilayah Utara. Masyarakat di kecamatan ini terdapat dua penutur bahasa daerah yaitu penutur bahasa Madura dan penutur bahasa Jawa. Selain itu, masyarakat di Kecamatan Randuagung ini juga menggunakan bahasa Indonesia apabila memang dibutuhkan. Bahasa Madura merupakan bahasa mayoritas yang berada di Kecamatan Randuagung sedangkan bahasa Jawa dan bahasa Indonesia merupakan bahasa minoritas. Bahasa Jawa biasanya digunakan oleh masyarakat penutur etnik Jawa. Masyarakat etnik Jawa yang berada di Kecamatan Randuagung rata-rata merupakan masyarakat pendatang yang kemudian tinggal menetap di kecamatan ini. Kondisi masyarakat yang terdapat dua penutur bahasa yang berbeda di satu lingkungan ini tidak menutup kemungkinan mereka tetap bisa berinteraksi antara penutur bahasa yang satu dengan penutur bahasa yang lainnya. Contoh, pada saat penutur yang berbahasa Madura berinteraksi dengan penutur yang berbahasa Jawa mereka tetap bisa melakukan interaksi dengan bahasa Indonesia meskipun mereka tidak mahir dalam bahasa tersebut. Mereka yang juga bisa menguasai bahasa Indonesia akan mencampur bahasa mereka dengan bahasa Indonesia. Apabila salah satu dari mereka tetap ada yang tidak dimengerti saat terjadi interaksi tersebut, mereka akan menekankan satu kata atau menunjuk sesuatu yang dia anggap lawan tuturnya akan lebih bisa dimengerti apa yang dimaksudkan. Dengan demikian mereka bisa melakukan pemilihan bahasa. 
Berkaitan dengan itu, Chaer dan Agustina (2010:153-154) menyatakan bahwa memilih bahasa ada tiga jenis pilihan yang dapat dilakukan oleh masyarakat tutur, yaitu: pertama yang disebut dengan alih kode, penutur menggunakan satu bahasa pada satu keperluan, dan menggunakan bahasa yang lain pada keperluan lain. Kedua, dengan melakukan campur kode, artinya menggunakan satu bahasa tertentu dengan dicampuri serpihan-serpihan dari bahasa lain. Ketiga, yaitu dengan memilih satu variasi bahasa yang sama atau yang juga disebut dengan tunggal bahasa.Selain dengan sebutan pemilihan bahasa, ada juga yang menyebut dengan pilihan bahasa, yaitu Sumarson. Menurut Sumarsono (2002:199) pilihan bahasa (language choice) ini tentu tergantung kepada faktor-faktor yang sudah kita kenal, seperti partisipan, suasana, topik, dan lain sebagainya.

Dengan demikian dapat dikatakan bahwa pemilihan bahasa yang digunakan oleh masyarakat tidak lepas dari campur kode (code mixing), alih kode (code switching) dan tunggal bahasa. Hal itu disebabkan oleh penguasaan dua bahasa atau lebih akan membuat seseorang dengan sengaja menggunakan kedua bahasa tersebut secara bersamaan. Melakukan campur kode artinya yaitu mereka menggunakan satu bahasa tertentu dengan mencampur serpihan-serpihan dari bahasa lain, sedangkan dikatakan seseorang melakukan alih kode apabila seseorang itu menggunakan satu bahasa pada sutu keperluan dan menggunkan bahasa yang lain pada keperluan lain dalam satu peristiwa komunikasi. Bebeda dengan campur kode dan alih kode, tunggal bahasa ini merupakan penggunaan satu bahasa dalam suatu interaksi antara penutur dan lawan tuturnya.

Secara keseluruhan penelitian ini mengidentifikasi suatu proses interaksi sosial yang terjadi di ranah transaksi jual beli di pasar Randuagung dengan menganalisis pemilihan bahasa yang dilakukan oleh penjual terhadap pembeli dalam wujud alih kode, campur kode, fan tunggal bahasa. Penggunaan bahasa dalam proses interaksi jual beli di pasar dengan latar belakang penjual maupun pembeli yang dapat menguasai dua bahasa atau lebih akan muncul suatu pemilihan bahasa yang dilakukan oleh penjual ataupun pembeli tersebut. Selain itu, faktor-faktor yang melatarbelakangi seseorang memilih bahasa tersebut dalam bertutur juga merupakan suatu hal yang menarik apabila diteliti. Secara keseluruhan memang masyarakat yang menjalin interaksi di pasar tidaklah semuanya menguasai lebih dari satu bahasa. Namun, justru orang yang menguasai lebih dari satu bahasa yang berada di lingkungan Pasar Randuagung tersebut akan menarik untuk diteliti karena berbeda dengan penutur lainnya.

\section{METODE}

Metode penelitian ini menggunakan jenis metode penelitian kualitatif deskriptif karena dalam mengkaji datanya berasal dari hasil pengamatan melalui wawancara, rekaman, dan menyimak. Kemudian, data-data tersebut dijabarkan secara deskriptif. Penelitian ini juga menggunakan metode penelitian berdasarkan tahapan strategisnya yang terdiri atas tiga yaitu: 1) tahap penyediaan data, 2) tahap analisis data, 3) tahap penyajian hasil analisis data.

Metode penyediaan data yang pertama menggunakan metode simak dengan teknik sadap, teknik simak bebas libat cakap dan teknik rekam. Metode penyediaan data yang kedua menggunakan metode cakap untuk mencari data tentang faktor-faktor yang melatarbelakangi terjadinya pemilihan bahasa yang dilakukan oleh penjual dan pembeli. Metode analisis data 
menggunakan metode padan intralingual dengan teknik-tekniknya untuk memecahkan permasalahan yang pertama, yaitu untuk menganalisis unsur lingual bahasa berbeda yang terdapat di dalam bahasa. Penelitian ini juga menggunakan metode padan ekstralingual untuk menganalisis unsur yang bersifat ekstralingual, seperti menghubungkan masalah bahasa dengan hal yang berada di luar bahasa untuk mengetahui faktor-faktor sosial dan situasi yang melatarbelakangi terjadinya campur kode, alih kode, dan tunggal bahasa. Pada tahap akhir yaitu tahap pemaparan hasil analisis data menggunakan metode informal yaitu metode dengan menggunakan kata dan atau kalimat (Sudaryanto 1993; Mahsun 2005).

\section{HASIL DAN PEMBAHASAN}

Pemilihan bahasa yang dilakukan oleh penjual dan pembeli di Pasar Kecamatan Randuagung Kabupaten Lumajang terjadi dalam wujud alih kode, campur kode, dan tunggal bahasa. Selain wujud pemilihan bahasa, dalam pembahasan ini juga akan dibahas tentang faktor-faktor yang melatarbelakangi pemilihan bahasa baik yang dilakukan oleh penjual maupun pembeli.

\section{Wujud Pemilihan Bahasa dalam Interaksi Jual-Beli}

Pemilihan bahasa yang dilakukan oleh penjual dan pembeli di Pasar Randuagung Kabupaten Lumajang berwujud alih kode, campur kode, dan tunggal bahasa. Pemilihan bahasa yang berwujud alih kode, campur kode dan tunggal bahasa dideskripsikan sebagai berikut.

\section{Pemilihan Bahasa Berupa Alih Kode}

Konteks Peristiwa:

Tuturan dilakukan oleh penjual cemilan di Pasar Randuagung. Penjual I (Siti Romla, 49 tahun) beretnik Madura yang dapat berbahasa Madura, Jawa, dan Indonesia. Penjual II (Halima, 20 tahun) merupakan anak dari Penjual I, yang menguasai bahasa Madura dan bahasa Indonesia. Pembeli (Nur, 46 tahun) beretnik Jawa, menggunakan bahasa Jawa untuk melakukan transaksi jual beli. Transaksi ini terjadi pada pukul 07.30 WIB di pasar Randuagung.

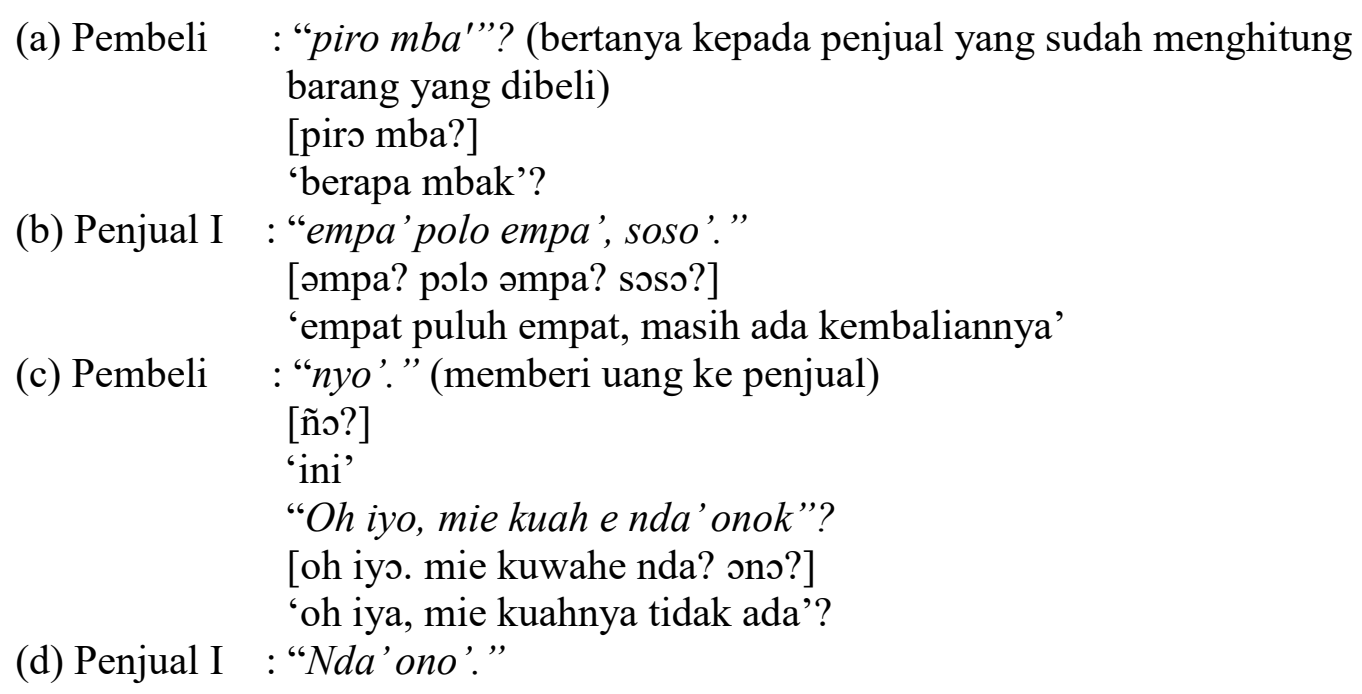




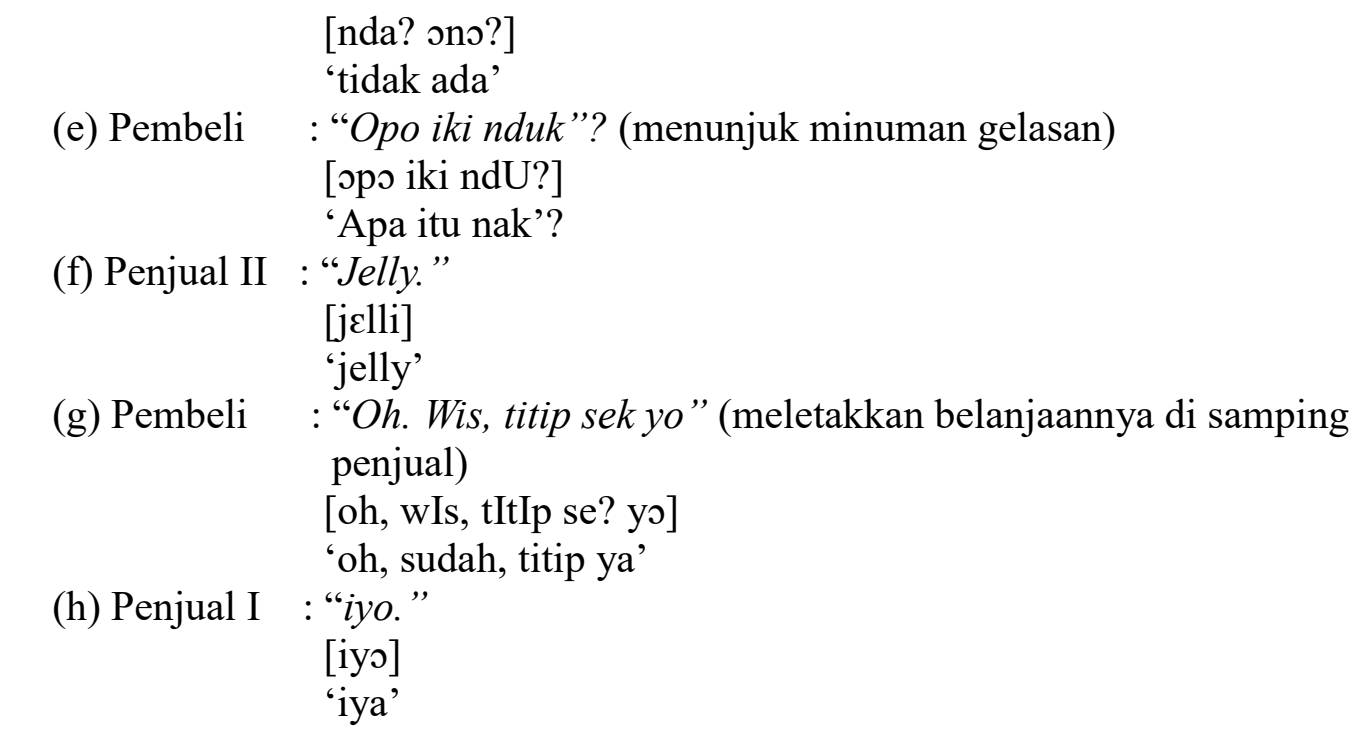

Data di atas menunjukkan bahwa bahasa yang dipakai oleh penjual dengan pembeli di awal-awal transaksi berbeda, yaitu pembeli memilih menggunakan bahasa Jawa dari awal sampai akhir traksaksi dilakukan, sedangkan penjual diawal traksaksi menggunakan bahasa Madura untuk membalas tuturan si pembeli. Seperti yang terlihat dalam percakapan tersebut, Penjual I berusaha melayani pembeli dengan menggunakan bahasa yang sama dengan pembeli. Hal tersebut terjadi karena Penjual I dengan pembeli hubungannya kurang akrab. Jadi, dalam percakapan tersebut pemilihan bahasa yang dilakukan oleh penjual yaitu bahasa Madura di awal percakapan. Kemudian, karena pembeli ini selalu menggunakan bahasa Jawa untuk bertransaksi, beralihlah bahasa yang digunakan penjual yaitu yang awalnya memilih bahasa Madura beralih ke bahasa Jawa untuk menjawab tuturan pembeli. Penjual beralih ke bahasa Jawa yaitu untuk menyamakan bahasa dengan pembeli agar tercipta komunikasi yang lebih baik dan penjual juga memahami bahasa Jawa tersebut.

Pemilihan bahasa dalam transaksi jual beli ini termasuk pemilihan bahasa dalam wujud alih kode. Alih kode tersebut dilakukan oleh Penjual I dalam transaksi tersebut. Alih kode tersebut dapat dilihat dalam tuturan (b) dan (d). Pada tuturan (b) Penjual I menjawab tuturan pembeli dengan mengucapkan "empa' polo empa', soso'." yang merupakan bahasa Madura yang artinya 'empat puluh empat, masih ada kembaliannya'. Kemudian beralihlah bahasa yang digunakan oleh Penjual I untuk mengimbangi bahasa yang digunakan oleh lawan tuturnya, yang semula memilih bahasa Madura untuk menjawab tuturan pembeli beralih memilih bahasa Jawa dalam menjawab tuturan pembeli berikutnya. Hal ini terdapat dalam tuturan (d) yaitu “Nda'ono'. ” yang merupakan bahasa Jawa yang artinya 'tidak ada'.

\section{Pemilihan Bahasa Berupa Campur Kode}

Konteks Peristiwa:

Interaksi jual beli pada data di bawah ini terjadi antara penjual cabai dengan pembeli di Pasar Randuagung. Penjual (Tomi, 45 tahun) beretnik Madura yang berbahasa Madura dan sedikit menguasai bahasa Jawa dan Indonesia, sedangkan pembeli ( $\mathrm{Bu} \mathrm{Su}, 54$ tahun) beretnik 
Jawa menggunakan bahasa Jawa dalam bertransaksi. Transaksi ini terjadi pada pukul 08.50 WIB di pasar Randuagung.

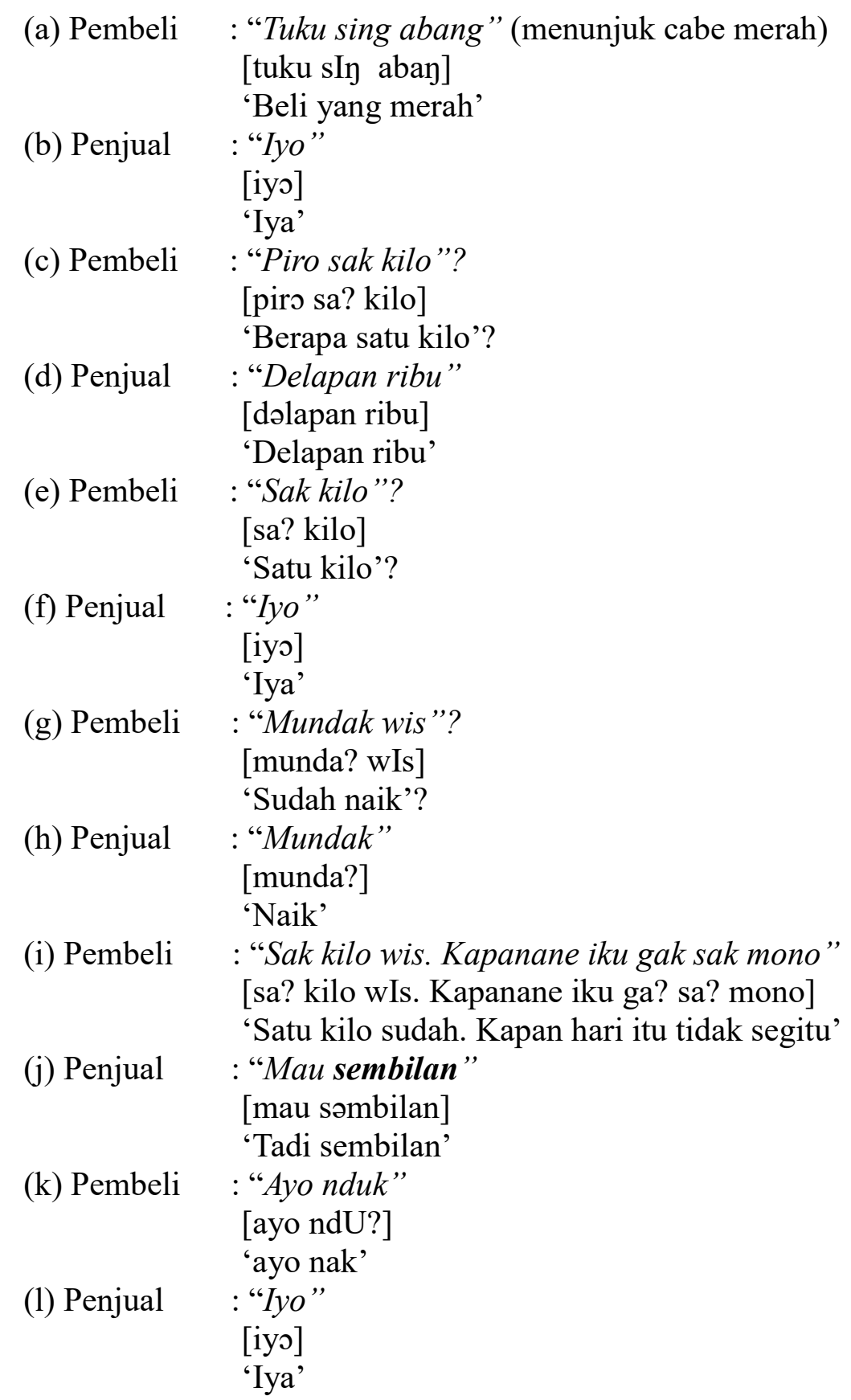

Data di atas menunjukkan bahwa bahasa yang digunakan oleh penjual dengan pembeli dari awal sampai akhir transaksi relatif sama yaitu menggunakan bahasa Jawa. Akan tetapi dalam tuturan tersebut penjual mencampur atau memasukkan kata-kata bahasa Indonesia ke dalam bahasa Jawa dalam menjawab tuturan pembeli. Penjual tetap menggunakan bahasa Jawa dalam menjawab tuturan pembeli, akan tetapi tidak selalu menggunakan bahasa jawa dengan penuh, terdapat serpihan-serpihan bahasa lain, yaitu bahasa Indonesia. Hal ini termasuk dalam pemilihan bahasa dalam wujud campur kode. 
Campur kode dalam transaksi jual beli tersebut hanya dilakukan oleh penjual. Campur kode yang dilakukan oleh penjual terjadi pada tuturan (j) "Mau sembilan" [mau səmbilan]. Pada tuturan tersebut, kata "mau" merupakan kata bahasa Jawa yang dalam bahasa Indonesia artinya 'tadi'. Kata "sembilan" merupakan kata bahasa Indonesia yang menunjukkan angka, sedangkan kata "sembilan" dalam bahasa Jawanya "sanga".

\section{Pemilihan Bahasa Berupa Tunggal Bahasa}

Konteks Peristiwa:

Interaksi jual-beli pada data (01) terjadi antara penjual kosmetik (Sumiati, 48 tahun) beretnik Jawa dengan pembeli (Hikma, 22 tahun) beretnik Madura. Transaksi terjadi pada pukul 09.40 WIB di Pasar Randuagung.
(a) Pembeli : "Beli bedak Pixy” [bəli bəda? Pixy]
'Beli bedak Pixy'
(b) Penjual : "Semuanya yang baru gini sekarang” (menunjuk bedak-bedak yang ada di etalasenya) [səmuaña yay baru gini səkaray] 'Semuanya yang baru seperti ini sekarang'
(c) Pembeli : : 'Ini ajalah Buk yang kecil Bu'” (menunjuk bedak yang kecil) [ini ajalah Bu? yan kəcil bu?]
(d) Penjual : "Yang kecil"? [yan kəcil] 'Yang kecil'? [iya] 'Iya'
(e) Pembeli : "Iya" [yan mana de?] 'Yang mana Dek'?
(f) Penjual : "Yang mana Dek”?
(g) Pembeli : "Yang ini” (menunjuk salah satu bedak) [yay ini] 'Yang ini'
(h) Penjual : "Ini”? (memperlihatkan bedak yang dipilih oleh pembeli) [ini] 'Ini'?
(i) Pembeli : : $Y a$ " [ya] 'Ya'
(j) Penjual : "Yang ini? ohh iya ya, yang ini yang besar" (mengambil bedak yang besar)
[yay ini oh iya ya, yay ini yay bəsar]
(k) Pembeli : "Iya" 'Yang ini? oh ya, yang ini yang besar'
[iya] 


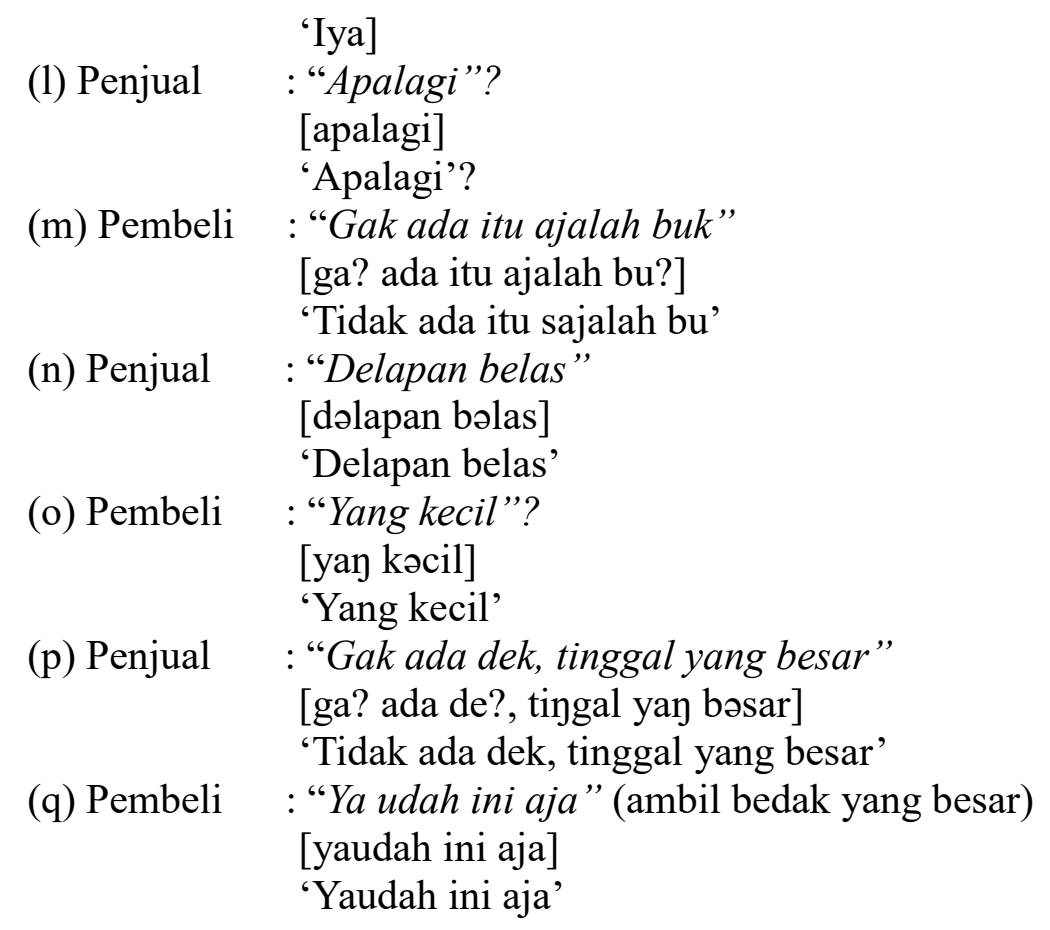

Pada data di atas tidak terjadi alih kode dan campur kode. Bahasa yang dipilih oleh penjual dan pembeli dalam bertransaksi dari awal sampai akhir percakapan sama, yaitu bahasa Indonesia. Bahasa Indonesia yang digunakan adalah ragam informal. Bahasa Indonesia ragam informal tersebut ditandai dengan leksikon bahasa Indonesia ragam informal, seperti kata gini 'begini' dan udah 'sudah'. Data tersebut menunjukkan bahwa bahasa yang dipilih oleh penjual dan pembeli merupakan tunggal bahasa, yaitu sama-sama menggunakan bahasa Indonesia ragam informal. Pembeli kenal dengan penjual, akan tetapi tidak akrab. Pembeli memilih bahasa Indonesia untuk memulai pembicaraan dengan penjual, karena pembeli tahu bahwa penjual tidak menguasai bahasa Madura seperti yang digunakannya sehari-hari. Pembeli yang beretnik Jawa yang menguasai bahasa Jawa dan Indonesia lebih memilih bahasa Indonesia yang digunakan untuk membalas tuturan pembeli. Pembeli bukan merupakan pelanggan dari toko tersebut, jadi penjual mengikuti bahasa yang digunakan oleh pembelinya.

\section{Faktor-faktor yang Melatarbelakangi Pemilihan Bahasa dalam Interaksi Jual-Beli}

Berdasarkan penelitian yang telah dilakukan, terdapat faktor-faktor yang melatarbelakangi penjual dan pembeli dalam memilih bahasa saat berinteraksi. Faktor-faktor pemilihan bahasa tersebut yaitu, participants (partisipan), topik percakapan, dan fungsi (maksud dan tujuan) tuturan. Pada penelitian ini, faktor partisipan dibagi menjadi beberapa cakupan, yaitu jarak sosial, perbedaan umur, latar belakang etnik dan bahasa penutur, serta hadirnya pihak ketiga. Berikut analisis faktor yang melatar belakangi pemilihan bahasa yang dilakukan oleh penjual dan pembeli di Pasar Randugung. 


\section{Participants (Partisipan)}

Participants (Partisipan) adalah pihak-pihak yang terlibat dalam tuturan tersebut, yaitu pembicara dan pendengar. Partisipan dalam penelitian ini adalah penjual dan pembeli yang melakukan interaksi jual-beli di pasar. Pada penelitian ini, faktor partisipan dibagi menjadi beberapa cakupan, yaitu: jarak social atau keakraban, perbedaan umur, latar belakang etnik dan bahasa penutur, hadirnya pihak ketiga, serta prestise.

Keakraban. Yang dimaksud keakraban yaitu tingkat keakraban yang terjalin antara penjual dengan pembeli, artinya bahwa kode bahasa yang digunakan oleh penjual pada saat bertransaksi dengan pembeli yang berbeda etnik atau yang sama etnik dan sudah akrab. Interaksi jual-beli diawali dengan percakapan penjual yang menggunakan bahasa Madura, kemudian pembeli membalasnya menggunakan bahasa Madura. Dalam percakapan tersebut penjual sesekali juga menggunakan bahasa Indonesia dan Jawa dalam berinteraksi dengan pembeli. Bahasa yang dipilih oleh keduanya yaitu bahasa Madura ragam enjấ-iyâ, karena dilatarbelakangi oleh faktor keakraban yang terjalin antara penjual dan pembeli.

Perbedaan umur. Faktor perbedaan umur yang dimaksud yaitu penjual atau pembeli yang umurnya lebih muda atau lebih tua. Penjual pada saat bertransaksi dengan pembeli yang lebih muda, akan berbeda bahasa yang dipilih ketika ia bertransaksi dengan pembeli yang lebih tua. Begitupun yang dilakukan oleh pembeli saat bertransaksi dengan penjual yang lebih muda atau tua. Hal ini dibuktikan saat interaksi jual beli dimulai ketika Pembeli I menanyakan barang kepada penjual dengan menggunakan bahasa Madura, kemudian dijawab oleh penjual menggunakan bahasa Madura juga tapi tingkat tuturnya engghi enten 'tingkat tinggi/halus' karena Pembeli I usianya lebih tua dari Penjual. Dengan hadirnya Pembeli II dan III membuat penjual tidak hanya menggunakan bahasa Madura, tetapi juga menggunakan bahasa Indonesia, karena Pembeli II dan III sebaya umurnya.

Latar belakang etnik dan bahasa penutur. Latar belakang etnik dan bahasa penutur juga termasuk faktor yang melatarbelakangi pemilihan bahasa yang dilakukan oleh penjual dan pembeli di pasar Randuagung. Penjual dan pembeli yang beretnik Madura rata-rata mereka menggunakan bahasa Madura dalam bertransaksi. Begitu juga dengan penjual dan pembeli yang beretnik Jawa akan menggunakan bahasa Jawa. Pemilihan bahasa yang dilakukan oleh penjual dan pembeli yang beretnik sama akan berbeda bahasa yang dipilih oleh penjual dan pembeli dengan latar belakang etnik yang berbeda.

Hadirnya pihak ketiga. Faktor hadirnya pihak ketiga yang dimaksud adalah hadirnya Pembeli II yang datang bergabung dengan Penjual yang sedang berinteraksi dengan Pembeli II. Saat Penjual dan Pembeli I berinteraksi dengan menggunakan bahasa Madura, tiba-tiba datang Pembeli II yang menggunakan bahasa Indonesia karena tidak menguasai bahasa Madura. Oleh karena itu, Penjual dan Pembeli I yang sebelumnya berinteraksi menggunakan bahasa Madura beralih ke bahasa yang digunakan oleh Pembeli II yaitu bahasa Indonesia. Hal itu dilakukan untuk menghargai pihak ketiga/Pembeli II yang datang bergabung dalam transaksi jual beli. Beralihnya bahasa yang dipilih oleh penjual itu dilakukan untuk menghormati Pembeli II yang baru datang dan menanyakan apa yang dicari kepada Pembeli II. Setelah menanyakan kepada Pembeli II itu, percakapan dengan Pembeli I tetap dilanjutkan dengan menggunakan bahasa Madura. Namun, sesekali penjual juga menyelipkan kata atau 
kalimat bahasa Indonesia.

Prestise. Prestise adalah sebuah status sosial, kehormatan dan kedudukan yang dimiliki oleh seseorang, dalam kategori lebih banyak atau lebih tinggi dari orang lain yang ada di lingkungan sekitarnya. Pada umumnya orang yang memiliki prestise dalam kehidupan sosial akan lebih dihormati dan disegani oleh masyarakat di sekitarnya dan hal itu akan membuatnya menjadi seseorang yang istimewa dan menonjol di antara orang-orang sekitarnya. Penjual dan pembeli yang berada di sekitar Pasar Randuagung juga melakukan hal yang berhubungan dengan prestise. Prestise yang diberikan oleh pembeli dengan memilih kata "Mi (Umi)" untuk memanggil Penjual karena kata Abah dan Umi adalah sebuah panggilan berbahasa Arab yang mempunyai arti 'Ayah' dan 'Ibu'. Panggilan Abah dan Umi diberikan kepada mereka yang bergelar Haji atau Hajjah, panggilan tersebut dirasa lebih istimewa bagi mereka yang telah menjalankan ibadah Haji. Begitu juga yang dilakukan oleh pembeli terhadap penjual dengan memanggil Mi atau Umi, karena status yang dimiliki oleh penjual yang sudah berhaji. Pembeli tidak memanggil dengan sebutan ibu atau lainnya, karena untuk memberikan penghormatan atau prestise terhadap penjual yang sudah bergelar hajjah tersebut. Begitu juga saat Pembeli I memilih bahasa dengan menggunakan bahasa Madura halus kepada penjual karena bahasa Madura halus digunakan kepada orang yang berprestise tinggi.

\section{Topik Percakapan}

Topik percakapan yang dimaksud adalah inti dari percakapan penjual dan pembeli. Hal ini dapat dilihat dari data hasil interaksi antara penjual dan pembeli. Di awal percakapan pmnanyakan kabar pembeli dengan menggunakan bahasa Indonesia.Kemudian, di tengahtengah percakapan, pembeli beralihlah bahasa saat menanyakan perihal baju yang dibeli beberapa waktu lalu. Hal itu sudah menunjukkan bahwa saat topik percakapan berubah, bahasa yang dipilihnya juga cenderung berubah. Perubahan pemilihan bahasa Indonesia menjadi bahasa Jawa yang dilakukan oleh penjual itu agar percakapan lebih terdengar santai, akrab, dan tidak terlalu formal. Percakapan yang semula menanyakan perihal pembeli yang sudah lama tidak datang ke toko, beralih topik percakapan tentang sesuatu yang dibeli beberapa waktu lalu.

\section{Fungsi (Maksud dan Tujuan) Tuturan}

Yang dimaksud fungsi (maksud dan tujuan) tuturan adalah maksud dan tujuan dilakukannya tuturan tersebut, seperti tuturan dengan tujuan untuk humor (berhumor), penawaran, penyampaian informasi, atau sekedar percakapan biasa sehari-hari. Penjual dan pembeli dalam melakukan transaksi kadang menyelipkan kata atau kalimat humor. Kata atau kalimat humor tersebut biasanya dilakukan oleh mereka yang hubungan sosialnya akrab. Berdasarkan data yang diperoleh, fungsi (maksud dan tujuan) tuturan tersebut yaitu tuturan dengan maksud humor atau berhumor. Tuturan humor tersebut dilakukan oleh Pembeli II kepada penjual yang memang hubungan sosial mereka akrab. Tuturan humor yang dilakukan oleh Pembeli II bisa dilihat pada tuturan "Bedeh oréng meturuk." yang merupakan kalimat dalam bahasa Madura yang dalam bahasa Indonesia berarti 'Ada orang titip'. Kata "meturuk" merupakan kata yang diplesetkan, yang sebenarnya bahasa Madura dari 'titip' yaitu 
"metorok" [mətorok]. Tujuan Pembeli mengatakan dengan kalimat seperti itu untuk melakukan humor atau lelucan dengan penjual yang memang sudah akrab.

\section{SIMPULAN}

Berdasarkan analisis atas permasalahan-permasalahan penelitian, dapat disimpulkan bahwa pemilihan bahasa yang dilakukan oleh penjual dan pembeli di Pasar Kecamatan Randuagung Kabupaten Lumajang penjual cenderung memilih bahasa yang digunakan dengan mengikuti bahasa pembeli. Ketika pembeli beretnik Jawa memilih menggunakan bahasa Jawa dalam berinteraksi dan penjual yang juga menguasai bahasa yang dipilih oleh pembeli akan menjawab tuturan dengan bahasa yang sama. Begitu pula pada saat pembeli beretnik Madura mengetahui bahwa penjual tidak menguasai bahasa Madura, pembeli yang juga menguasai bahasa Jawa atau bahasa Indonesia akan memilih menggunakan bahasa Jawa atau Indonesia sesuai dengan bahasa yang juga dikuasai oleh penjual.

Pemilihan bahasa dalam penelitian ini dijabarkan dalam beberapa wujud pemilihan bahasa, yaitu: wujud alih kode, campur kode atau tunggal bahasa. Wujud pemilihan bahasa dalam suatu interaksi jual-beli di Pasar Kecamatan Randuagung dilakukan oleh keduanya yaitu penjual dan pembeli atau hanya dilakukan oleh penjual atau pembelinya saja.

Faktor-faktor yang melatarbelakangi pemilihan bahasa yang dilakukan oleh penjual dan pembeli saat berinteraksi, yaitu: faktor participants (partisipan), topik percakapan, dan fungsi (maksud dan tujuan) tuturan. Faktor participants (partisipan) dibagi lagi menjadi beberapa cakupan, yaitu: jarak sosial, perbedaan umur, latar belakang etnik dan bahasa penutur, serta hadirnya pihak ketiga.

Dalam penelitian ini penulis hanya membahas pemilihan bahasa dalam wujud alih kode, campur kode dan tunggal bahasa beserta faktor-faktor yang melatarbelakangi pemilihan bahasa tersebut. Oleh karena itu, diharapkan pada penelitian berikutnya peneliti lain dapat meneliti dari sudut pandang yang berbeda, lebih kompleks dan menyeluruh atau membahas tentang penggunaan bahasa dari segi kajian semantik, pragmatik dan sosiolinguistik lainnya.

\section{DAFTAR PUSTAKA}

Chaer, A. dan Agustina, L. 2010. Sosiolinguistik Perkenalan Awal (Edisi Revisi). Jakarta: Rineka Cipta.

Mahsun. 2005. Metode Penelitian Bahasa. Jakarta: PT Raja Grafindo Persada.

Sudaryanto. 1993. Metode dan Aneka Teknik Analisis Bahasa. Yogyakarta: Duta Wacana University Press.

Sumarsono. 2002. Sosiolinguistik. Yogyakarta: Pustaka Pelajar. 